J. Perinat. Med. 17 (1989) 465

\section{Cord IgM levels in placentas with villitis of unknown etiology}

\author{
Albina M. Altemani', Andrea Fassoni' ${ }^{1}$, and Sergio Marba ${ }^{2}$ \\ ${ }^{1}$ Department of Pathology, ${ }^{2}$ Department of Pediatrics, State University of Cam- \\ pinas, Brazil
}

\section{Introduction}

Placental villitis is a lesion which has been associated with transplacental infection of the fetus, especially with virus [5]. Villitis of unknown etiology (VUE) is the largest category of the villitides and small-for-gestational-age infants (SGA) is its major clinical association $[3,8,9$, 15]. The reported incidence of VUE varies in different countries $[2,3,8,9,15]$. The highest frequencies have been described in South America $[2,9]$.

The possibility that a higher incidence of intrauterine infection could explain the high frequency of VUE in developing countries [10] led us to determine the incidence of raised IgM levels (a non-specific monitor to intrauterine infections [1] in cord serum of placentas with VUE.

\section{Material and methods}

A total of 86 placentas were collected. All the placentas were from singleton pregnancies, being $82,5 \%$ full-term pregnancies. Sixty-seven cases were from infants above the 10th percentile weight for gestational age in the ponderal curve [11]. These infants were considered adequate-forgestational-age (AGA) and 46 of these cases were from non-complicated pregnancies and 21 from complicated pregnancies by preeclampsia (6 cases) or sustained chronic hypertension (15 cases). Nineteen cases were from infants below the 10th percentile weight. These latter infants were considered SGA infants and their mothers had had uncomplicated pregnancies in 10 cases, chronic hypertension in three and preeclampsia in six. The infants did not have clinical evidence of congenital infection and serologic reactions

\section{Curriculum vitae}

Albina M. Altemani, M.D., was born in 1953. She was graduated from the State University of Campinas, Brazil, in 1976 and specialized in Pathology at the same University until 1979. She is currently on the staff of the Department of Pathology, State University of Campinas. Her main field of interest is perinatal pathology, particularly pathology of the placenta.

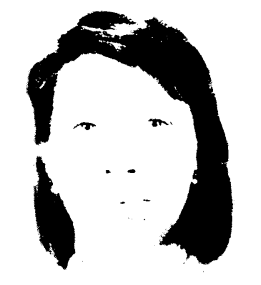

for syphilis were negative in all cases. The placentas were fixed whole in $10 \%$ formalin several days. After external examination they were cut into slices. Ten blocks were taken: four from paracentral areas of the placental parenchyma, four from the central portion of the basal area of the placenta, one of membranes and one of umbilical cord. All the histological sections were stained with hematoxylin and eosin. Villitis was diagnosed only when there was clear-cut evidence of inflammatory cell infiltration of villi [6]. Cord serum was obtained from the 86 placentas. One to three samples were taken and stored at $-70^{\circ} \mathrm{C}$ until used. IgM level was measured on radial immunodiffusion plates LC-Partigen IgM (Behringwerke AG, Marburg, Germany) and the samples were read against standard concentrations of immunoglobulins (human protein-standard-serum LCA, Behringwerke). IgM levels of $20 \mathrm{mg} \%$ or above were considered abnormally high. Double determinations were done when the IgM levels were $15 \mathrm{mg} \%$ or higher [16]. 


\section{Results}

Villitis of unknown etiology (figure) was found in 36 placentas $(41.8 \%)$ being severe or moderate in ten cases $(27.7 \%)$. In the AGA group this lesion occurred in $22.8 \%$ of the placentas, while in the SGA group VUE was found in $42.1 \%$. Basal villitis [15] was observed in 23 cases. The incidence of this lesion in the AGA group was $31.3 \%$ and in SGA $10.5 \%$.

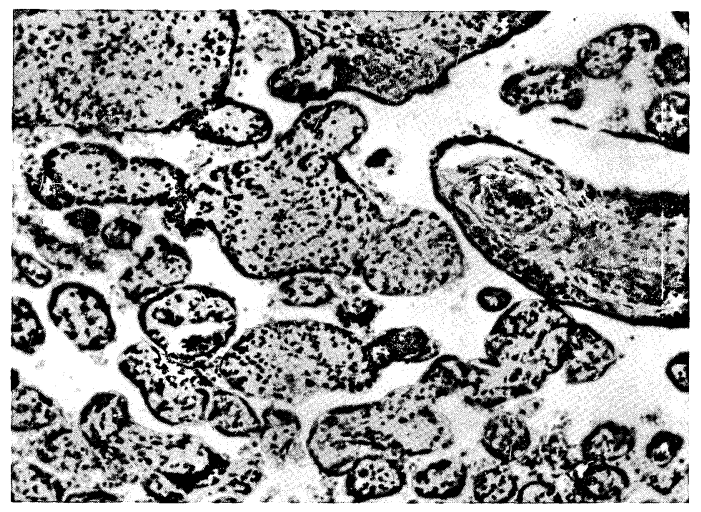

Figure. Villitis of unknown etiology. Some villi are inflamed in this field. $\mathrm{HE} \times 125$.

Raised IgM levels were found in 8 out of 50 placentas without villitis $(16 \%)$ and in 5 out of 36 with villitis $(13.8 \%)$. These five infants with villitis and raised IgM level were phisically normal, full-term and only one was SGA infant. Acute inflammation of the membranes, a factor that can also be associated with raised IgM levels, was investigated and found in three cases. Only one of these had VUE. In the remaining cases, without villitis and/or amniotic infection, the reason for the IgM elevation was not evident.

\section{Discussion}

The incidence of VUE in different countries varies from 6 to $68 \%[3,4,8,9,15]$, being the highest that reported by LABARRERE et al [9] in Argentina. Our frequency of VUE was $41.8 \%$ and the lesion predominated in SGA infants, a relationship that has been frequently noted $[4$, $7-9,15]$. Two main possible origins have been suggested to the VUE: a) maternal infection [4, 15] and b) maternal immune attack against placental tissues [9]. In relation to the former hypothesis it is possible that a higher frequency of intrauterine infections in developing countries [14] may affect the incidence of VUE.

The frequency of VUE found by us was high $(41.8 \%)$, but our incidence of raised IgM levels in placentas with VUE (13.8\%) was low and similar to that reported by MORTIMER and SMEETH [13] in the UK (10\%) and by ALTSHULER and RUSSELL [3] in the USA (16\%). Nevertheless, the incidences of VUE reported by these authors were significantly lower as compared to ours.

The hypothesis of that a higher frequency of intra-uterine infection in developing countries may affect the incidence of VUE is not necessarily false because of our findings. In spite of IgM being usually a good parameter for intrauterine infection, a previously raised IgM could be normal at the time of delivery. In viral infections only in those cases where the virus persists in the tissues throughout pregnancy the IgM level would be raised [12]. On the other hand the low incidence of raised IgM and the absence of clinical evidence of congenital infection in the neonates with VUE could also support a not infectious etiology to the VUE, as was proposed by LABARRERE et al [9].

Therefore, we have to conclude that determination of cord IgM did not help significantly in the investigation of the cause of the high frequency of VUE in our series. It is possible that other factors, beyond intrauterine infections, such as ethnic or environmental, may lead to a variable incidence of VUE in different countries [8]. However, more detailed studies should be made.

\section{Abstract}

Villitis of unknown etiology (VUE) is the largest category of the placental villitides and its incidence varies in different countries. The possibility that a higher incidence of intrauterine infection could explain the high frequency of VUE in developing countries led us to determine the incidence of raised IgM levels (a non-
\end{abstract}

specific monitor to intrauterine infections) in cord serum of placentas with VUE. Eighty-six placentas were studied. Of these 67 were from infants with adequate weight for their gestational age (AGA) and 19 from infants small for their gestational age (SGA). IgM level in the cord serum was measured on radial 
immunodiffusion plates. VUE was found in 36 placentas $(41.8 \%)$ and it predominated in the SGA group. Raised IgM levels were found in only $13.8 \%$ of the placentas with VUE. In spite of our frequency of VUE being high, our incidence of raised IgM levels in pla-

Keywords: Immunoglobulin, placenta, villitis.

\section{Zusammenfassung}

IgM-Spiegel im Nabelschnurblut bei Plazenten mit einer Villitis unklarer Genese

In den meisten Fällen ist die Ätiologie einer plazentaren Villitis unbekannt (Villitis unklarer Ätiologie; VUÄ). Die Inzidenz ist in den verschiedenen Ländern unterschiedlich hoch [2, 3, 8, 9, 15]. Die Möglichkeit, $\mathrm{da} ß$ eine höhere Inzidenz von intrauterinen Infektionen die erhöhte Frequenz von VUÄ in sog. Entwicklungsländern erklären könnte [10], gab den Hinweis auf die Bestimmung der IgM-Spiegel im Nabelschnurblut von Plazenten mit einer VUÄ, wobei IgM als unspezifischer Marker einer intrauterinen Ifektion gilt [1]. Wir untersuchten 86 Plazenten; davon waren 76 von Kindern mit einem für das Gestationsalter adäquaten Geburts-

Schlüsselwörter: Immunglobulin, Plazenta, Villitis.

\section{Résumé}

Taux d'IgM au cordon dans les placentas avec inflammation villositaire d'étiologie inconnue

Les inflammations villositaires d'étiologie inconnue (VUE) représentent la catégorie la plus importante des inflammations des villosités placentaires et leur incidence varie selon les pays $[2,3,8,15]$.

Le fait qu'une incidence plus élevée des infections intrautérines puisse expliquer la grande fréquence des VUE dans les pays développés [10] nous a conduit à déterminer l'incidence des taux élevés d'IgM (moyen de surveillance non spécifique des infections intra-utérines [1]) dans le sang du cordon des placentas avec VUE. On a étudié quatre vingt six placentas. Parmi ceux-ci 67 provenaient d'enfants ayant un poids normal pour leur âge gestationnel (AGA) et 19 enfants petits pour centas with VUE was low and similar to that reported by authors who have low incidence of VUE in their series. We conclude that determination of cord IgM did not help significantly in the investigation of the cause of the high frequency of VUE in our series.

gewicht (AGA) und 19 von Small-for-date-Kindern (SGA). Die IgM-Spiegel im Nabelschnurblut wurden mittels radialer Immundiffusion gemessen. Eine VUÄ ließ sich in 36 Plazenten (41.8\%) nachweisen, wobei die SGA-Gruppe stärker betroffen war. Erhöhte IgMSpiegel fanden wir jedoch lediglich in $13.8 \%$ der Plazenten mit VUÄ. Trotz einer hohen Frequenz von VUÄ war die Inzidenz erhöhter IgM-Spiegel bei diesen Plazenten gering. Sie war nicht höher als in den Untersuchungsreihen, in denen die Inzidenz einer VUÄ gering war [3, 13]. Sucht man also nach Ursachen für die hohe Frequenz von VUÄ in unserem Untersuchungsgut, scheint die Bestimmung des IgM im Nabelschnurblut nicht hilfreich zu sein.

leur âge gestationnel (SGA). Les taux d'IgM dans le sang du cordon ont été mesurés sur des disques d'immunodiffusion radiaire. On a trouvé des VUE dans 36 placentas $(41,8 \%)$ et elles prédominent dans le groupe SGA. On a trouvé des taux élevés d'IgM dans seulement $13,8 \%$ des placentas avec VUE. Malgré notre fréquence élevéede VUE, notre incidence de taux élevés d'IgM dans les placnetas avec VUE est faible et similaire à celle qui est rapportée par les auteurs qui ont une incidence basse de VUE dans leurs séries $[3,13]$. Nous concluons que la détermination des IgM au sang du cordon n'apporte pas d'aide significative à l'investigation de la cause de la fréquence élevée des VUE dans nos séries.

Mots-clés: Immunoglobuline, inflammation villositaire, placenta,

Acknowledgements: This research was supported by FAPESP proc. 86/0603-8.

\section{References}

[1] Alford CA, S Stagno, D Reynolds: Diagnosis of chronic perinatal infections. Am J Dis Child 129 (1975) 455
[2] Altemani AM, LA ANDrade, MA Brenelli, OR GRASSIOTO, AM BACHA: Vilosite placentária. Correlação anátomo-clínica. J Ped 52 (1982) 315 
[3] Altshuler G, P Russell: The human placental villitides: a review of chronic intrauterine infection. In Current Topics in Pathology. SpringerVerlag, Berlin 1975

[4] Altshuler G, P Russell, R Ermocilla: The placental pathology of small for gestational age infants. Am J Obstet Gynecol 121 (1975) 351

[5] Fox H: Pathology of the placenta. WB Saunders, London 1978

[6] Fox H: Placental involvement in maternal systemic infection. In: RoSENBERG HS, J BERNSTEIN: Perspective in Pediatric Pathology, Vol 6 Year Book Medical, Chicago 1981

[7] GARCIA AGP: Placental morphology of low-birthweight-infants born at term-gross and microscopic study of 50 cases. Contr Gynec Obstet 9 (1982) 100

[8] KNOX WF, H Fox: Villitis of unknown aetiology: its incidence and significance in placentae from a British population. Placenta 5 (1984) 395

[9] Labarrere C, O Althabe, M Telenta: Chronic villitis of unknown aetiology in placentae of idiopathic small for gestational age infants. Placenta 3 (1982) 309

[10] LAGA EM, SG Driscoll, HN Munro: Comparison of placentas from two socio-economic groups. I Morphometry. Pediatrics 50 (1972) 24
[11] LubChenco LO, DT SeARls, JV BrozIE: Neonatal mortality rate: relationship to birth weight and gestational age. J Pediat 81 (1972) 814

[12] Mc Kay E, H Thom, D Gray: Immunoglobulins in umbilical cord plasma. II Congenital deformities, other abnormalities and multiple pregnancies. Arch Dis Child 42 (1967) 264

[13] Mortimer G, A Smeeth: A pilot study of the frequency and significance of placental villitis. $\mathrm{Br}$ J Obstet Gynaec 92 (1985) 629

[14] Naeye RL, WA Blanc: Relation of poverty and race to antenatal infection. New Engl J Med 283 (1970) 555

[15] RuSSELL P: Inflammatory lesions of the human placenta III The histopathology of villitis of unknown aetiology. Placenta 1 (1980) 227

[16] SEVER JL: Immunoglobulin determinations for the detection of perinatal infections. J Pediat 75 (1969) 1111

Received July 15, 1989. Accepted August 10, 1989.

Albina M. Altemani, M. D.

Departamento de Anatomia Patológica

FCM-UNICAMP

Campinas

SP, Brasil 13081 